\title{
Analisis Tingkat Kerusakan Lemak Nabati dan Lemak Hewani Akibat Proses Pemanasan
}

\author{
${ }^{1,2}$ Sandra Hermanto*, ${ }^{1}$ Anna Muawanah, ${ }^{2}$ Prita Wardhani \\ ${ }^{1)}$ Program Studi Kimia FST UIN Syarif Hidayatullah Jakarta \\ ${ }^{2)}$ Pusat Laboratorium Terpadu UIN Syarif Hidayatullah Jakarta \\ Jl. Ir. H. Juanda No. 95 Ciputat Jakarta 15142 \\ email : $\underline{\text { sandra.hermanto@gmail.com }}$
}

\begin{abstract}
Abstrak
Penelitian ini bertujuan untuk mengetahui stabilitas dan tingkat kerusakan lemak nabati dan lemak hewani akibat proses pemanasan pada suhu tinggi. Beberapa lemak nabati dan lemak hewani yang dijadikan sampel dalam penelitian ini meliputi minyak goreng curah, minyak goreng kemasan, minyak ikan, margarine, lemak babi, lemak sapi, lemak ayam dan minyak zaitun. Masing-masing sampel dipanaskan pada suhu $110^{\circ} \mathrm{C}$ selama 30 menit, selanjutnya stabilitas dan tingkat kerusakannnya dianalisis dengan mengukur kadar radikal bebas melalui analisis malondialdehid dengan metode kolorimetri dan komposisi asam lemak jenuh (saturated fatty acid), asam lemak tak jenuh tunggal (mono unsaturated fatty acid) serta asam lemak tak jenuh ganda (poly unsaturated fatty acid) dengan menggunakan Gas Chromatography Mass Spectrofotometry (GCMS). Hasil penelitian menunjukkan bahwa kandungan radikal bebas sebagai parameter kerusakan lemak pada masing-masing sampel relatif berbeda dimana pada minyak ikan dihasilkan radikal bebas sebesar $40 \mu \mathrm{mol} / \mathrm{L}$, sedangkan pada minyak goreng curah sebesar $25 \mu \mathrm{mol} / \mathrm{L}$, minyak goreng kemasan $20 \mu \mathrm{mol} / \mathrm{L}$, margarine $16 \mu \mathrm{mol} / \mathrm{L}$, minyak zaitun $30 \mu \mathrm{mol} / \mathrm{L}$, lemak ayam $37 \mu \mathrm{mol} / \mathrm{L}$, lemak sapi $18 \mu \mathrm{mol} / \mathrm{L}$ dan lemak babi $31 \mu \mathrm{mol} / \mathrm{L}$. Hasil analisa GCMS menunjukkan bahwa kandungan asam lemak jenuh terbesar diperoleh pada sampel lemak sapi (65.53\%), sedangkan asam lemak tidak jenuh ganda terbesar diperoleh pada minyak ikan sebesar $30.24 \%$. Hal ini mengindikasikan bahwa tingkat kerusakan lemak pada masing-masing sampel sangat dipengaruhi oleh kandungan awal asam lemak tak jenuh ganda yang terdapat pada masing-masing sampel seperti pada minyak ikan dimana komposisi asam lemak tidak jenuh ganda relatif lebih besar dibandingkan dengan yang lain.
\end{abstract}

Kata kunci : Tingkat kerusakan lemak, lemak nabati, lemak hewani, radikal bebas, GCMS

\begin{abstract}
This study aims to determine the stability and level of fats damage due to the heating process at high temperature. Some vegetable fats and animal fats are used as samples in this study include bulk cooking oil, packaged cooking oil, fish oil, margarine, lard, beef fat, chicken fat and olive oil. Each sample is heated at a temperature of $110^{\circ} \mathrm{C}$ for 30 minutes, then the stability and level of fats damage were analyzed by measuring the levels of free radicals through the malondialdehyde formation with colorimetric methods and then the composition of saturated fatty acids, monounsaturated fatty acids and polyunsaturated fatty acids were determined by using Gas Chromatography Mass Spectrofotometry (GCMS). The results showed that the content of free radical damage to fats as a parameter in each of the samples was relatively different, in which the free radicals of fish oil generated by $40 \mu \mathrm{mol} / \mathrm{L}$, while in the bulk cooking oil $25 \mu \mathrm{mol} / \mathrm{L}$, packaged cooking oils $20 \mu \mathrm{mol} / \mathrm{L}$, margarine $16 \mu \mathrm{mol} / \mathrm{L}$ and olive oil $30 \mu \mathrm{mol} / \mathrm{L}$, . GCMS analysis results showed that the largest saturated fatty acid content was obtained on samples of beef tallow (65.53\%), while the largest unsaturated fatty acids was obtained in fish oil at $75.48 \%$. These indicate that the level of damage to the fat in each sample is strongly influenced by the initial amount of polyunsaturated fatty acids, where the fish oil sample was relatively larger than that another oils.
\end{abstract}

Keywords: Level of fats damage, vegetable fats, animal fats, free radicals, GCMS 


\section{PENDAhUluan}

Lemak dan minyak merupakan zat makanan yang penting untuk menjaga kesehatan tubuh manusia. Selain itu lemak dan minyak juga merupakan sumber energi yang lebih efektif dibanding dengan karbohidrat dan protein. Satu gram minyak atau lemak dapat menghasilkan 9 kkal, sedangkan karbohidrat dan protein hanya menghasilkan $4 \mathrm{kkal} / \mathrm{gram}$ (Muchtadi, et.al., 1992).

Lemak dan minyak terdapat pada hampir semua bahan pangan dengan kandungan yang berbeda-beda, tetapi lemak dan minyak sering kali ditambahkan dengan sengaja ke bahan makanan dengan berbagai tujuan. Dalam pengolahan bahan pangan, minyak dan lemak berfungsi sebagai media penghantar panas, seperti minyak goreng, shortening (mentega putih), lemak (gajih), mentega, dan margarine. Disamping itu, penambahan lemak juga dimaksudkan untuk menambah kalori serta memperbaiki tekstur dan cita rasa bahan pangan., seperti pada kembang gula, penambahan shortening pada pembuatan kuekue, dan lain-lain. Lemak yang ditambahkan kedalam bahan pangan, atau dijadikan bahan pangan membutuhkan persyaratan dan sifat-sifat tertentu. Berbagai bahan pangan seperti daging, ikan, telur, susu, alpokat, kacang tanah, dan beberapa jenis sayuran mengandung lemak atau minyak yang biasanya termakan bersama bahan tersebut. Lemak dan minyak tersebut dikenal sebagai lemak tersembunyi (invisible fat). Sedangkan lemak dan minyak yang telah diekstraksi dari ternak atau bahan nabati dan dimurnikan dikenal sebagai minyak biasa atau lemak kasat mata (visible fat) (Ketaren, 1986).

Lemak nabati atau minyak nabati adalah sejenis minyak yang terbuat dari tumbuhan dan banyak digunakan dalam makanan, sebagai perisai rasa (flavor), untuk menggoreng dan memasak. Beberapa jenis minyak nabati yang biasa digunakan ialah minyak kelapa sawit, minyak jagung, minyak zaitun, minyak kedelai, dan minyak biji bunga matahari. Berdasarkan kegunaannya, minyak nabati terbagi atas dua golongan. Pertama, minyak nabati yang dapat digunakan dalam industri makanan (edible oils) dan dikenal dengan nama minyak goreng meliputi minyak kelapa, minyak kelapa sawit, minyak zaitun, minyak kedelai, minyak kanola dan sebagainya. Kedua, minyak yang digunakan dalam indutri non makanan (non edible oils), misalnya minyak kayu putih, minyak jarak, dan minyak intaran (Anonim. 2009).

Minyak dapat digunakan sebagai medium penggoreng bahan pangan. Karena dapat berfungsi sebagai medium penghantar panas, menambah rasa gurih, menambah nilai gizi dan kalori dalam bahan pangan. Tetapi pemanasan minyak secara berulang-ulang pada suhu tinggi dan waktu yang cukup lama, akan menghasilkan senyawa polimer yang berbentuk padat dalam minyak. Senyawa padat tersebut lama kelamaan akan teroksidasi menghasilkan senyawa-senyawa radikal bebas yang merugikan kesehatan. Terdapat beberapa sumber radikal bebas antara lain adalah sumber internal yang meliputi superoksida dari hasil reduksi $\mathrm{O}_{2}$ pada saat sel mengalami fagositosis, hiskemia atau reaksi Fenton. Radikal bebas juga dapat dihasilkan dari sumber eksternal seperti yang berasal dari makanan yang mengandung lemak, makanan yang digoreng, zat warna makanan, pengawet dan polutan udara. (Halliwell, et.al. 1989).

Kerusakan minyak selama proses penggorengan akan mempengaruhi mutu dan nilai gizi dari bahan pangan yang digoreng. Pada lemak dan minyak dikenal ada dua tipe kerusakan yang utama, yaitu ketengikan dan hidrolisis. Ketengikan terjadi bila komponen cita-rasa dan bau mudah menguap terbentuk sebagai akibat kerusakan oksidatif dari lemak dan minyak yang tak jenuh. Komponenkomponen ini menyebabkan bau dan cita-rasa yang tidak dinginkan dalam lemak dan minyak dan produk-produk yang mengandung lemak dan minyak (Raharjo, S. 2004). Kerusakan minyak yang menimbulkan ketengikan dapat terjadi karena proses pemanasan. Dalam penelitian ini dilakukan proses pengujian untuk mengetahui sejauh mana tingkat kerusakan dan stabilitas asam lemak dari beberapa produk lemak nabati dan lemak hewani yang dipanaskan selama beberapa menit melalui analisis kandungan malondialdehid (MDA) sebagai parameter 
kerusakan lemak dan analisis komposisi asam lemak dengan menggunakan alat GCMS.

\section{METODE PENELITIAN}

\section{Bahan dan Alat}

Bahan-bahan yang digunakan terdiri dari minyak goreng curah dan minyak goreng kemasan yang diperoleh dari Pasar Ciputat Tangerang sedangkan minyak ikan, margarine, dan minyak zaitun diperoleh dari supermarket. Lemak hewani (lemak ayam, lemak sapi dan lemak babi) diperoleh dari jaringan lemak daging ayam, sapi dan babi yang diperoleh dari Rumah Pemotongan Hewan (RPH). Pelarut nheksan untuk melarutkan lemak, Larutan TBA (Thiobarbituric acid) $0,37 \%$ dan larutan MDA*(malondialdehid) $0.02 \mathrm{M}$ untuk analisis tingkat kerusakan lemak, $\mathrm{Na}_{2} \mathrm{SO}_{4}, \mathrm{KOH} 10 \%$, BF3 dalam methanol untuk transesterifikasi lemak.

Spektrofotometer UV-Vis Perkin Elmer Lambda 25 untuk analisis radikal bebas, Gas Chromatoghrapy Mass Spectrofotometry (GCMS) QP-2010 Shimadzu Japan dengan Kolom RTx1-MS, Restech $30 \mathrm{~m} \times 0.25 \mathrm{~mm} I D$, $0.25 \mu \mathrm{m}$, Polymethyl xiloxane (polydimethyl xiloxane $100 \%$ ) untuk analisis asam lemak.

\section{Preparasi Sampel}

Lemak hewani diekstrak dari jaringan lemak dengan cara pemanasan menggunakan oven pada suhu $75^{\circ} \mathrm{C}$ selama 24 jam. Setelah lemak terekstrak, lemak disaring dengan kertas saring Whatman yang ditambah $\mathrm{Na}_{2} \mathrm{SO}_{4}$ anhidrat sebanyak dua kali penyaringan. Sampel lemak yang tersaring disimpan dalam wadah tertutup dan ditempatkan dalam desikator. Sedangkan untuk sampel lemak cair disiapkan dalam wadah gelas sebanyak $5 \mathrm{~mL}$ dan disimpan dalam desikator.

\section{Uji Tingkat Kerusakan Lemak}

Pengukuran tingkat kerusakan lemak dilakukan menggunakan alat spektrofotometri UV-visible dengan larutan TBA sebagai reagen pembentuk warna (metode kolorimetri). Masing-masing sampel lemak sebelumnya dipanaskan dalam ruang terbuka pada suhu $110^{\circ} \mathrm{C}$ selama 30 menit. Setelah dingin, ke dalam sampel lemak ditambahkan pelarut n-heksan dan aquades dengan volume yang sama. Senyawa radikal bebas yang dihasilkan diekstraksi dengan corong pisah dan dipisahkan dari lapisan lemak. Larutan Malondialdehid yang dihasilkan akan bereaksi dengan TBA membentuk senyawa kompleks TBA-MDA berwarna merah muda. Intensitas warna yang dihasilkan diukur pada panjang gelombang $532 \mathrm{~nm}$ dan nilai absorbansinya sebanding dengan kadar radikal bebas yang dihasilkan (Moore K, et.al., 1998).

\section{Analisa komposisi asam lemak dengan GCMS}

Sebelum sampel lemak dianalisa dengan GCMS, terlebih dahulu dilakukan esterifikasi dengan cara memasukkan 2 gram sampel lemak/minyak yang telah diekstrak ke dalam tabung reaksi dan direaksikan dengan $\mathrm{BF}_{3}$ dalam metanol. Campuran dikocok dan dipanaskan selama \pm 15 menit. Selanjutnya didiamkan sampai terbentuk 2 lapisan. Lapisan atas dipisahkan dengan sentrifugasi dan dipurifikasi lebih lanjut dengan menambahkan $\mathrm{Na}_{2} \mathrm{SO}_{4}$ untuk menghilangkan kadar airnya. Hasil esterifikasi dimasukkan ke dalam vial untuk dianalisis lebih lanjut dengan alat GCMS $1 \mu \mathrm{L}$ sampel lemak yang telah diesterifikasi diinjeksikan ke dalam kolom GC dengan menggunakan metode autosampler. Pemisahan dilakukan dalam kolom RTx 1-MS Restech, $30 m \times 0.25$ mm ID, 0.25 $\mu m$, dengan fase diam Poly dimethyl xiloxane, suhu injektor $280^{\circ} \mathrm{C}$, suhu kolom $70^{\circ} \mathrm{C}$ dinaikan sampai $300^{\circ} \mathrm{C}$ dengan kenaikan $10^{\circ} \mathrm{C} /$ menit, laju alir 1,15 mL/menit (David F, Sandra P., 2005). Detektor MS yang digunakan adalah Electron Multifier Detector (EMD) $70 \mathrm{MeV}$. Hasil analisis berupa spektrum massa dibandingkan dengan library WILLEY147 \& NIST47 yang terdapat pada software GCMS postrun analysis. (Janusz Czarniecki, 1998). 


\section{HASIL DAN PEMBAHASAN}

\section{Tingkat kerusakan lemak berdasarkan hasil uji radikal bebas}

\begin{abstract}
Stabilitas lemak nabati dan lemak hewani sangat berkaitan dengan tingkat kerusakan lemak. Pada umumnya lemak yang tidak stabil cenderung akan terhidrolisis atau teroksidasi menghasilkan senyawa radikal bebas. Senyawa radikal bebas yang dihasilkan ini sebanding dengan tingkat kerusakan lemak dimana pada pemanasan dengan suhu yang relatif tinggi dan lamanya proses pemanasan mampu meningkatkan kadar radikal bebas sehingga kerusakan lemak tersebut akan semakin besar (Saifudin, U. 2008). Di bawah ini adalah beberapa jenis radikal bebas dan reactive oxygen species (ROS) yang berperan dalam proses kerusakan sel.
\end{abstract}

Tabel 1. Jenis radikal bebas yang berperan dalam kerusakan sel

\begin{tabular}{|l|c|l|c|}
\hline \multicolumn{1}{|c|}{$\begin{array}{c}\text { Radikal } \\
\text { bebas }\end{array}$} & Lambang & \multicolumn{1}{|c|}{ ROS } & Lambang \\
\hline Hidroksil & $\mathrm{OH}^{*}$ & $\begin{array}{l}\text { Hidrogen } \\
\text { Peroksida }\end{array}$ & $\mathrm{H}_{2} \mathrm{O}_{2}$ \\
\hline Superoksida & $\mathrm{O}_{2}{ }^{*}$ & $\begin{array}{l}\text { Singlet } \\
\text { Oksigen }\end{array}$ & ${ }^{\mathrm{I}} \mathrm{O}_{2}$ \\
\hline Nitrit Oksida & $\mathrm{NO}^{*}$ & $\begin{array}{l}\text { Asam } \\
\text { Hipoklorida }\end{array}$ & $\mathrm{HOCl}$ \\
\hline Lipid Oksida & LOO $^{*}$ & Ozon & $\mathrm{O}_{3}$ \\
\hline
\end{tabular}

(Sumber : Haliwell B, and Gutteridge JMC. 1989)

Radikal bebas merupakan senyawa kimia yang tidak stabil, terbentuk di dalam tubuh selama metabolisme normal atau paparan racun dari lingkungan seperti pencemaran udara, pencemaran makanan dan air. Radikal bebas membantu tubuh kita untuk menghasilkan energi dan melawan infeksi, tetapi ketika konsentrasinya terlalu banyak radikal bebas dapat menyerang sel sehat sehingga menyebabkan kerusakan sel.

Jumlah kandungan radikal bebas yang dihasilkan selama proses autooksidasi lipid dapat ditentukan secara kuantitatif dengan metode kolorimetri lipid peroksidasi (Moore, K., et.al., 1998). Hasil analisis kandungan radikal bebas pada beberapa sampel lemak nabati dan lemak hewani yang diuji dengan metode kolorimetri peroksidasi lipid adalah sebagai berikut :

Tabel 2. Hasil uji radikal bebas (Parameter kerusakan lemak)

\begin{tabular}{|c|l|c|}
\hline No. & Sampel Lemak & $\begin{array}{c}\text { Kadar radikal } \\
\text { bebas }\end{array}$ \\
\hline 1. & Minyak goreng curah & $25 \mu \mathrm{mol} / \mathrm{L}$ \\
\hline 2. & $\begin{array}{l}\text { Minyak goreng } \\
\text { kemasan }\end{array}$ & $20 \mu \mathrm{mol} / \mathrm{L}$ \\
\hline 3. & Margarine & $16 \mu \mathrm{mol} / \mathrm{L}$ \\
\hline 4. & Minyak ikan & $40 \mu \mathrm{mol} / \mathrm{L}$ \\
\hline 5. & Minak zaitun & $30 \mu \mathrm{mol} / \mathrm{L}$ \\
\hline 6. & Lemak ayam & $37 \mu \mathrm{mol} / \mathrm{L}$ \\
\hline 7. & Lemak Sapi & $18 \mu \mathrm{mol} / \mathrm{L}$ \\
\hline 8. & Lemak Babi & $31 \mu \mathrm{mol} / \mathrm{L}$ \\
\hline
\end{tabular}

Dari hasil penelitian yang dilakukan (Tabel 2) terlihat bahwa kadar radikal bebas terbesar diperoleh pada minyak ikan, yakni sebesar $40 \mu \mathrm{mol} / \mathrm{L}$, selanjutnya disusul dengan lemak ayam (37 $\mu \mathrm{mol} / \mathrm{L})$, lemak babi (31 $\mu \mathrm{mol} / \mathrm{L})$ dan minyak zaitun (30 $\mu \mathrm{mol} / \mathrm{L})$. Tingginya kadar radikal bebas kemungkinan disebabkan karena komposisi asam lemak pada minyak goreng curah sebagaian besar merupakan asam lemak tak jenuh seperti asam oleat, linoleat dan linolenat. Asam lemak tak jenuh sangat mudah mengalami autooksidasi terutama pada keadaan kaya oksigen dan adanya uap air serta proses pemanasan. Penelitian yang dilakukan oleh, K. Umano, et.al, 1988, menyebutkan bahwa proses autooxidasi pada minyak jagung dan lemak sapi setelah irradiasi selama 8 jam menghasilkan malondialdehid sebesar 56,24 ug/g dan 25,01 ug/g, dengan produk radikal bebas lainnya yang teridentifikasi sebagai derivatif methylhydrazine. Faktor penyimpanan dan kandungan logam berat juga mampu mengkatalisis terjadinya reaksi autooksidasi lebih cepat (F. W. Heaton et.al., 1960). Penelitian yang dilakukan Van Rollins et.al., (1984), menyebutkan bahwa proses autooksidasi asam lemak tak jenuh pada temperatur di atas $65^{\circ} \mathrm{C}$ akan menghasilkan 
senyawa turunan monoasil dihidroksi asam lemak dengan reaksi sebagai berikut :

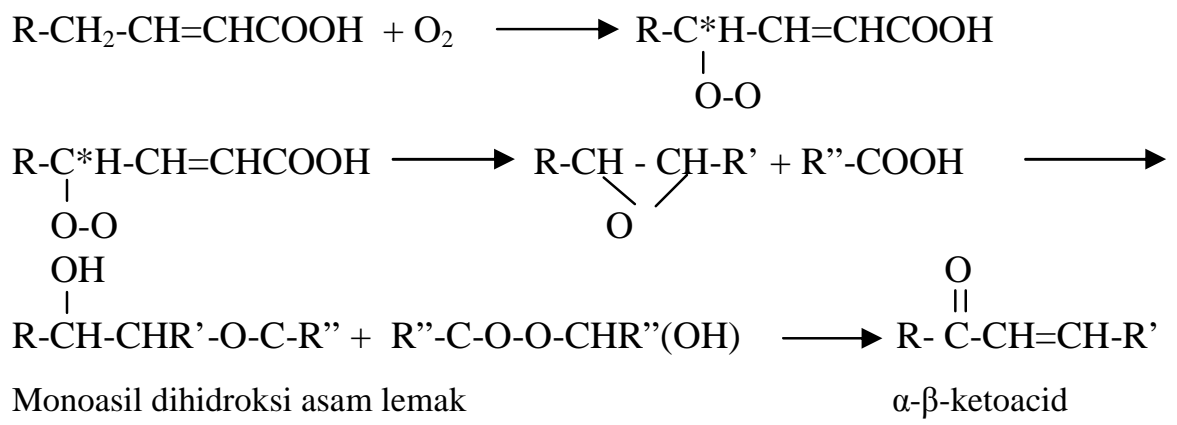

Senyawa monoasil dihidroksi asam lemak tersebut selanjutnya akan mengalami reaksi hidrolisis membentuk senyawa $\alpha-\beta$ ketoacid yang secara bertahap akan membentuk senyawa turunan aldehid dan radikal bebas. (F. W. Heaton et.al., 1961), mengungkapkan bahwa oksidasi asam lemak menghasilkan senyawa hidroperoksida yang kemudian akan mengalami dekomposisi lebih lanjut menghasilkan senyawa alkohol, aldehid dan hidrokarbon. Senyawa tersebut berperan dalam pembentukan flavor ketengikan dan warna hitam dari minyak.

Jumlah radikal bebas yang terbentuk bergantung pada banyaknya ikatan rangkap yang teroksidasi sehingga untuk sampel lemak yang kandungan asam lemak tak jenuh relatif besar cenderung akan menghasilkan radikal bebas dalam jumlah besar. Asam lemak tak jenuh yang mengandung ikatan rangkap lebih dari satu, terutama ikatan ikatan rangkap terkonjugasi, akan lebih mudah teroksidasi. Hasil penelitian Van Rollins, et.al., (1984), menunjukkan bahwa ester asam lemak bersifat lebih stabil daripada asam lemak bebas. Namun demikian, panjang rantai karbon tidak signifikan mempengaruhi autoksidasi asam lemak tak jenuh. Pada beberapa lemak nabati yang kaya akan ikatan rangkap tak jenuh, semakin jauh posisi ikatan rangkap dari gugus karboksil, maka reaktivitasnya semakin rendah.

\section{Hasil analisa komposisi asam lemak dengan GCMS}

Untuk mengetahui komposisi relatif asam lemak jenuh (Saturated fatty acid/SFA) dan asam lemak tak jenuh tunggal (Mono unsaturated fatty acid/MUFA) serta asam lemak tak jenuh ganda (Polyunsaturated fatty acid/PUFA), masing-masing sampel lemak dianalisis dengan alat GCMS QP 2010 menggunakan kolom RTX-1MS melalui metode transesterifikasi dengan cara menderivatisasi asam lemak menjadi senyawa turunannya yakni metil ester asam lemak (fatty acid methyl ester). Derivatisasi dilakukan untuk menurunkan titik didih dari masing-masing asam lemak agar lebih mudah diuapkan dan dipisahkan sehingga menghasilkan pemisahan dengan resolusi yang lebih baik. Pemisahan derivat asam lemak (fatty acid methyl ester) dilakukan dalam kondisi suhu kolom $70^{\circ} \mathrm{C}$ dan dinaikkan sampai $300^{\circ} \mathrm{C}$ dengan kenaikan $10^{\circ} \mathrm{C} /$ menit dengan laju alir 1,15 $\mathrm{mL} / \mathrm{menit}$. Adapun hasil analisis komposisi asam lemak untuk masing-masing sampel lemak adalah sebagai berikut : 
Tabel 3. Komposisi asam lemak dari lemak nabati \& hewani hasil analisa GCMS

\begin{tabular}{|c|c|c|c|c|c|c|c|c|}
\hline \multirow{2}{*}{ Jenis asam lemak } & \multicolumn{8}{|c|}{ Jumlah relatif asam lemak $(\%)$} \\
\hline & MGC & MGK & $\mathrm{MR}$ & $\mathrm{MI}$ & $\mathrm{MZ}$ & $\overline{L A}$ & $\overline{\mathrm{LS}}$ & LB \\
\hline Asam Kaproat (C6:0) & $\mathrm{td}$ & 0.02 & $\mathrm{td}$ & $\mathrm{td}$ & $\mathrm{td}$ & $\mathrm{td}$ & $\mathrm{td}$ & $\mathrm{td}$ \\
\hline Asam Kaprrilat (C8:0) & $\mathrm{td}$ & 0.03 & $\mathrm{td}$ & $\mathrm{td}$ & $\mathrm{td}$ & $\mathrm{td}$ & $\mathrm{td}$ & 0.02 \\
\hline Asam Kaprat (C10:0) & 0.1 & 0.57 & td & $\mathrm{td}$ & 1.27 & td & 0.2 & 0.04 \\
\hline Asam Laurat (C12:0) & 0.1 & 0.1 & 0.31 & $\mathrm{td}$ & $\mathrm{td}$ & $\mathrm{td}$ & 0.31 & 0.12 \\
\hline Asam Miristat (C14:0) & 0.67 & 0.31 & 2.76 & 2.15 & 2.3 & 0.74 & 4.36 & 1.28 \\
\hline $\begin{array}{l}\text { Asam } \\
(\mathrm{C} 16: 1)\end{array}$ & 0.4 & $\mathrm{td}$ & $\mathrm{td}$ & 5.1 & $\mathrm{td}$ & 7.01 & 1.4 & 1.31 \\
\hline Asam Palmitat (C16:0) & 27.56 & 28.89 & 35.12 & 7.97 & 8.18 & 27.24 & 29.4 & 23.1 \\
\hline Asam Margarat (C17:0) & 0.07 & $\overline{\mathrm{td}}$ & 0.13 & 0.11 & $\overline{\mathrm{td}}$ & $\mathrm{td}$ & 1.74 & 0.3 \\
\hline Asam Linolenat (C18:3) & 0.01 & 3.21 & 0.09 & 5.03 & 4.25 & 1.2 & $\mathrm{td}$ & $\mathrm{td}$ \\
\hline Asam Linoleat(C18:2) & 11.39 & 9.09 & 6.09 & 16.32 & 9.35 & 16.36 & 1.17 & 18.94 \\
\hline Asam oleat (C18:1) & 52.1 & 53.87 & 25.4 & 32.6 & 44.17 & 38.35 & 20.53 & 40.74 \\
\hline Asam Stearat (C18:0) & 4.65 & 3.7 & 13.7 & 3.9 & 5.2 & 5.56 & 31.26 & 13.96 \\
\hline $\begin{array}{ll}\text { Asam } & \text { Arakidonat } \\
(\mathrm{C} 20: 4) & \\
\end{array}$ & $\mathrm{Td}$ & 0.02 & $\mathrm{td}$ & 8.89 & 2.54 & 0.87 & $\mathrm{td}$ & 0.43 \\
\hline Asam Arakidat (C20:1) & 0.27 & $\mathrm{td}$ & $\mathrm{td}$ & 7.54 & 1.96 & 0.41 & $\mathrm{td}$ & $\overline{\mathrm{td}}$ \\
\hline Asam Arakhat(C20:0) & 0.6 & td & 0.58 & 0.35 & 0.54 & td & 0.33 & 0.2 \\
\hline Asam Behenat (C24:0) & td & td & td & 0.18 & 0.56 & td & 0.02 & td \\
\hline $\begin{array}{l}\text { Jumlah asam lemak } \\
\text { jenuh (SPA) }\end{array}$ & 33.75 & 33.57 & 63.89 & 14.02 & 16.95 & 33.54 & 65.53 & 38.52 \\
\hline $\begin{array}{l}\text { Jumlah asam lemak tak } \\
\text { jenuh tungal (MUFA) }\end{array}$ & 52.77 & 53.87 & 23.4 & 45.24 & 46.13 & 45.77 & 21.93 & 42.05 \\
\hline $\begin{array}{l}\text { Jumlah asam lemak tak } \\
\text { jenuh ganda (PUFA) }\end{array}$ & 11.4 & 12.32 & 6.18 & 30.24 & 16.14 & 18.43 & 1.17 & 19.37 \\
\hline Total MUFA + PUFA & 64.17 & 66.19 & 29.98 & 75.48 & 62.27 & 64.20 & 23.11 & 61.42 \\
\hline $\begin{array}{l}\text { Rasio as. lemak tak } \\
\text { jenuh/ jenuh }\end{array}$ & 1.90 & 1.97 & 0.46 & 5.38 & 3.67 & 1.91 & 0.35 & 1.59 \\
\hline $\begin{array}{l}\text { : Minyak C } \\
\text { : Minyak g } \\
\text { : Margarin }\end{array}$ & $\begin{array}{l}\text { ng Curah } \\
\text { ig kemasar }\end{array}$ & $\begin{array}{l}\text { MZ } \\
\text { LA } \\
\text { LS }\end{array}$ & $\begin{array}{l}\text { : Miny } \\
\text { : Lem } \\
: \text { lema }\end{array}$ & $\begin{array}{l}\text { Zaitun } \\
\text { yam } \\
\text { pi }\end{array}$ & $\begin{array}{l}\mathrm{LB} \\
\text { td }: \text { tidak te }\end{array}$ & $\begin{array}{l}\text { nyak Ikan } \\
\text { nak babi } \\
\text { eksi }\end{array}$ & & \\
\hline
\end{tabular}

Berdasarkan hasil analisa komposisi asam lemak pada masing-masing sampel terlihat bahwa persentasi asam lemak jenuh (SFA), asam lemak tak jenuh tunggal (MUFA) dan dan asam lemak tak jenuh ganda (PUFA) relatif berbeda. Kandungan asam lemak jenuh terbesar terdapat pada lemak sapi sebesar $65.53 \%$ dengan rasio (MUFA+PUFA)/SFA 0.35, dan lemak margarin sebesar 63.89\% dengan rasio (MUFA+PUFA)/SFA 0.46, sedangkan asam lemak tak jenuh terbesar terdapat pada minyak zaitun sebesar $82.27 \%$, minyak ikan $75.48 \%$ dan minyak goreng kemasan $66.19 \%$. Minyak ikan memiliki kandungan asam lemak tak jenuh ganda terbesar yaitu $30.24 \%$, sedangkan minyak zaitun sebesar $26.14 \%$. Kandungan asam lemak tak jenuh tunggal terbesar terdapat pada minyak goreng kemasan sebesar $53.87 \%$, dan minyak goreng curah sebesar 52.77\%. Rasio (MUFA+PUFA)/SFA terbesar diperoleh pada minyak ikan yaitu $5.38 \%$, kemudian minyak zaitun sebesar $3.67 \%$ dan lemak sapi $0.35 \%$. 
Perbedaan komposisi asam lemak pada masing-masing sampel sangat bergantung pada sumber lemak tersebut. Dengan rasio (MUFA+PUFA)/SFA yang besar dan persentasi asam lemak tak jenuh lebih besar maka kecenderungan untuk menghasilkan radikal bebas juga akan semakin besar. Jika dibandingkan dengan penelitian yang dilakukan Aftab Kandhro, et.al., (2007), pada margarin menunjukkan komposisi asam lemak jenuh, tak jenuh tunggal dan asam lemak tak jenuh ganda sebesar 24,2-58,1, 5,7-35,4 dan 3,8-37,4\% dari total asam lemak masing-masing, dimana asam palmitat $(16,9-33,8 \%)$ adalah yang dominan di semua merek margarin.

\section{KESIMPULAN}

Berdasarkan hasil analisa radikal bebas pada masing-masing sampel lemak nabati dan lemak hewani yang telah dipanaskan, tingkat kerusakan lemak terbesar terjadi pada sampel minyak ikan dengan kandungan radikal bebas sebesar $40 \mu \mathrm{mol} / \mathrm{L}$, sedangkan pada minyak goreng curah sebesar $25 \mu \mathrm{mol} / \mathrm{L}$, minyak goreng kemasan $20 \mu \mathrm{mol} / \mathrm{L}$, margarine $16 \mu \mathrm{mol} / \mathrm{L}$, minyak zaitun $30 \mu \mathrm{mol} / \mathrm{L}$, lemak ayam 37 $\mu \mathrm{mol} / \mathrm{L}$, lemak sapi $18 \mu \mathrm{mol} / \mathrm{L}$ dan lemak babi $31 \mu \mathrm{mol} / \mathrm{L}$. Banyaknya kandungan radikal bebas yang dihasilkan sangat dipengaruhi oleh komposisi dan reaktifitas dari masing-masing asam lemak yang terdapat pada setiap sampel.

\section{DAFTAR PUSTAKA}

1. Anonim. 2009. Minyak Nabati. http://id.wikipedia.org/wiki/Minyak_nabati

2. Ketaren S. 1986. Pengantar Teknologi Minyak dan Lemak Pangan. Jakarta : UI-Press.

3. Muchtadi, Tien. R dan Sugiyono. 1992. Ilmu Pengetahuan Bahan Pangan. Institut Pertanian Bogor. Bogor.

4. Raharjo, S. 2004. Kerusakan Oksidatif pada Makanan. Pusat Studi Pangan dan Gizi UGM. Yogyakarta

5. Saifudin, U. 2008. Analisa Lemak dan Minyak. Blog at WordPress.com.
6. Haliwell B, and Gutteridge JMC. 1989. Free Radical in Biology and Medicine.Oxford University Press. Ed 3. hlm 105-220

7. Moore K, Roberts LJ. 1998, Measurement of lipid peroxidation. Free Radic Res ;28: 659-667

8. K. Umano, K. J. Dennis and T. Shibamoto, 1988, Analysis of free malondialdehyde in photo irradiated corn oil and beef fat via a pyrazole derivative, Journal of Lipids, Vol. 23 No.8

9. Van Rollins M., Robert C Murphy, Autooxidation of Docosahexanoic Acid : Analysis of Isomers Of Hidroxydocosahexanoate, Journal of Lipid Research, Vol 25 hlm. 507-517.

10. Janusz Czarniecki, 1998, GC/MS Analysis for Unsaturated Fat Content in Animal Feed, GC/MS 48, Varian Nafag Company, Gossau, Switzerland

11. Aftab Kandhro, S.T.H. Sherazi, S.A. Mahesar, M.I. Bhanger, M. Younis Talpur and Abdul Rauf, 2007, GC-MS quantification of fatty acid profile including trans $F A$ in the locally manufactured margarines of Pakistan, Food Chemistry, Volume 109, Hlm. 207-211.

12. F. W. Heaton and N. Uri, 1961, The aerobic oxidation of unsaturated fatty acids and their esters: cobalt stearate-catalyzed oxidation of linoleic acid, Journal of Lipid Research, Vol. 2, 152-160. 